Mitcheld, P. \& Moyle, J. (1951). J. gen. Microbiol. 5, 966-980.

\title{
Isolation of Hydrolytic Products of a Glycerophospho- compound from Micrococcus pyogenes
}

\author{
By P. MITCHELL AND JENNIFER MOYLE \\ Department of Biochemistry, University of Cambridge
}

SUMMARY: The ribonucleic acid fraction of Micrococcus pyogenes var. aureus (strain Duncan), separated by the method of Schmidt \& Thannhauser (1945), contains organic phosphate in excess of that which can be accounted for by a polynucleotide nucleic acid structure. This 'excess phosphate' can be separated from the other phospho-compounds after fractional extraction of $M$. pyogenes in dilute acid or in dilute alkali. Four polyolphosphate compounds occur in the extracts. The main components are $\alpha$-and $\beta$-glycerophosphate, the two other polyolphosphates (giving water-insoluble barium salts; separable chromatographically) occurring in smaller amount. The yields of glycerophosphate show that at least $75 \%$ of the 'excess phosphate' is present in an easily hydrolysed glycerophospho-compound which may also be the origin of the unidentified polyolphosphates. The glycerophospho-compound of $M$. pyogenes accounts for more than one-quarter of the total organic phosphate of the organism. The presence of 'excess phosphate' in a number of Gram-positive organisms suggests that a glycerophospho-compound similar to that of $M$. pyogenes may be of general occurrence in Gram-positive bacteria and in yeasts.

In the course of checking a spectrophotometric method of estimating nucleic acid in intact cell suspensions (Mitchell, 1950a) against an adaptation of the method of Schmidt \& Thannhauser (1945) developed by Stephenson \& Moyle (1949), it was found that although the two methods were in substantial agreement when applied to Escherichia coli (strain $\mathrm{H}$ ), they did not agree when applied to Micrococcus pyogenes var. aureus (strain Duncan). Comparison of the light absorption at a wave-length of $260 \mathrm{~m} \mu$. with the organic phosphate content of the ribonucleic acid (RNA) fraction of the Schmidt \& Thannhauser method indicated that in $M$. pyogenes there was an excess of organic phosphate amounting to more than $30 \%$ of that which could be accounted for by a polynucleotide RNA structure (Mitchell, 1950 a). The occurrence of 'excess phosphate' in the RNA fractions of a number of micro-organisms showed a strong correlation with the capacity for retaining Gram's stain (Mitchell \& Moyle, 1950), and it was observed that the amount of 'excess phosphate' in $M$. pyogenes was decreased during growth in the presence of penicillin (Mitchell, 1950b; Mitchell \& Moyle, 1951).

It was desirable to begin a study of the origin of the 'excess phosphate' of the RNA fraction of Gram-positive bacteria not only to facilitate the elimination of errors in the estimation of RNA, but also to account for the occurrence of a large fraction of the total organic phosphate of these organisms. The present paper describes work on the separation and characterization of fragments of a phospho-compound containing the major part of the 'excess phosphate' of the RNA fraction of M. pyogenes var. aureus (strain Duncan), cultivated as described by Mitchell (1950a). 


\section{Definition and measurement of the 'excess phosphate'}

In the Schmidt \& Thannhauser (1945) method of estimating nucleic acids the cells are treated with cold $5 \%$ trichloroacetic acid to remove the inorganic phosphate and diffusible organic phosphate compounds. The lipid is then extracted with organic solvents and the residue is treated with $\mathrm{N}$ alkali at $37^{\circ}$ for $15 \mathrm{hr}$. to depolymerize the RNA. The deoxyribonucleic acid (DNA), which is resistant to the alkali treatment, is reprecipitated with $5 \%$ trichloroacetic acid, leaving the organic phosphate of RNA and inorganic phosphate of phosphoprotein in solution. This solution, referred to as the RNA fraction, contains the 'excess phosphate' in which we are interested.

It was convenient to express the quantity of 'excess phosphate' (XSP) as the number of $\mu \mathrm{mol}$. organic phosphate in excess of the number of $\mu \mathrm{mol}$. purine-pyrimidine in the RNA fraction from $1 \mathrm{~g}$. of organism dried in vacuo over $\mathrm{P}_{2} \mathrm{O}_{5}$ at room temperature. The organic phosphate was measured by the difference between determinations of total and inorganic phosphate by microadaptations of the methods of Fiske \& Subbarow (1925) giving values with a standard deviation of $\pm 1 \%$ for samples of 3-30 $\mu \mathrm{g}$. P and $\pm 5 \%$ for samples as small as $0.5 \mu \mathrm{g}$. P. The measurement of purine-pyrimidine on a comparable micro scale could be carried out only by absorption spectrophotometry. The extinction of the appropriately diluted solutions was determined at $260 \mathrm{~m} \mu$. with the Beckman spectrophotometer using quartz cuvettes giving a light path of $1 \mathrm{~cm}$. Owing to lack of information about the proportions of the purine and pyrimidine bases present in the RNA of $M$. pyogenes, there was doubt about the value of the mean molecular extinction coefficient to be used to relate the extinction at $260 \mathrm{~m} \mu$. to the mean molecular concentration of purine and pyrimidine base in the nucleotide fragments of the RNA fraction. The published values for the molecular extinction coefficient of the hypothetical nucleotide unit (identical with the mean molecular purine-pyrimidine extinction coefficient) of nucleic acids range from 6500 (Malmgren \& Hedén, 1947) to 9000 (Wyatt, 1950). It was therefore desirable to determine the mean molecular extinction coefficient for the purine-pyrimidine as present in the RNA of M. pyogenes.

The whole ribonucleoprotein of $\boldsymbol{M}$. pyogenes was isolated by the sonic disintegration and ammonium sulphate precipitation method of Sevag \& Smolens (1941), and the organic phosphate content and extinction coefficient at $260 \mathrm{~m} \mu$. were measured in neutral aqueous solution. Assuming the molecular concentrations of phosphate and base to be equal, the molecular

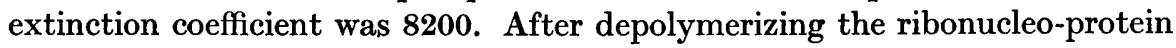
with $\mathrm{N}-\mathrm{NaOH}$ at $35^{\circ}$ for $15 \mathrm{hr}$., neutralization with $\mathrm{HCl}$ and precipitation of the protein with $5 \%$ trichloroacetic acid, the molecular extinction coefficient was found to be 10,000, in agreement with the value of 10,000 found by Wyatt (1950) for a pure yeast RNA preparation after a similar treatment. The mean molecular concentration of purine-pyrimidine in the RNA fraction was therefore estimated using the coefficient 10,000. The standard deviation of the purine-pyrimidine measurements was usually $c . \pm 3 \%$, the main cause of 
variation being the occasional occurrence of slight turbidity. We did not consider it advisable to correct for what has been cryptically described by certain workers as 'non-specific absorption'.

As a subsidiary datum, pentose determinations were carried out as by Mejbaum (1939), the period of heating with the orcinol reagent being extended from 15 to $60 \mathrm{~min}$. in order to obtain a more stable colour, the colour being determined photometrically. Pure crystalline ribose was used as a standard, and it was assumed that $65 \%$ of the pentose of the RNA of M. pyogenes would be estimated (Schneider, 1945). We confirmed the finding of ValyiNagy (1947) that the presence of phosphate causes a depression of the estimated pentose values. In addition to this relatively small effect, however, unknown substance present in Corynebacterium, Neisseria, certain Lactobacillus and Escherichia spp., and baker's yeast, changed the colour given by the orcinol reagent and diminished the extinction coefficient by as much as $50 \%$. It therefore seemed probable that in samples of unknown composition, such as those from the so-called nucleic acid fractions of bacteria, the estimation of pentose would be liable to unaccountable errors. Nevertheless, estimations of pentose were considered to be of use in confirming those of purine-pyrimidine, particularly when significance could be attached to relative changes in the pentose values.

\section{Separation of 'excess phosphate' from the nucleotide components}

The 'excess phosphate' might be present in the RNA fraction either as part of the RNA fragments or as a separate compound or group of compounds. Several attempts were made to separate phospho-compounds other than nucleotides from the mono- and poly-nucleotides of the RNA fraction, using ethanol fractionation of the barium and silver salts at various $\mathrm{pH}$ values; the separation being followed by the ratio of the extinction at $260 \mathrm{~m} \mu$. to the organic phosphate content of the fractions. These attempts, however, gave no indication of the existence of a phospho-compound not containing purinepyrimidine; nor were we able to obtain paper chromatographic separation of the components of the barium salt fractions.

An alternative procedure to the isolation of components of the whole RNA fraction was the fractional extraction of these components from the cells; for it would be expected that if the 'excess phosphate' were firmly bound to the RNA, the rates of extraction of organic phosphate, purine-pyrimidine and pentose by a given reagent would be the same, whereas if the rates were different the presence of some other phospho-compound might be indicated. The most convenient method for fractional extraction was by hydrolysis in dilute acid or alkaline solution.

Fractional extraction by alkali. In order to minimize the complicating effects of autolytic activity, it was advisable to carry out the extraction at a low temperature and at the highest $\mathrm{pH}$ giving a rate of extraction convenient for attempting to observe fractionation. Preliminary experiments showed that $0 \cdot 1 \mathrm{~N}-\mathrm{NaOH}$ at $0^{\circ}$ gave a suitable rate of extraction of organic phosphate.

In order to stop the hydrolysis when each sample of cell suspension in 
$0 \cdot 1 \mathrm{~N}-\mathrm{NaOH}$ was withdrawn, it was desirable to neutralize with acid. It was found, however, that neutralization with $\mathrm{HCl}$ gave erratic results which suggested reprecipitation of the extracted RNA. The effect of bringing the samples to different $\mathrm{pH}$ values was therefore examined. A washed suspension of $\boldsymbol{M}$. pyogenes was extracted with $5 \%$ trichloroacetic acid to remove diffusible purine-pyrimidine and phosphate compounds, and washed on the centrifuge with distilled water. The cells were then resuspended at a dry-weight concentration of $10 \mathrm{mg} . / \mathrm{ml}$. in $0 \cdot 1 \mathrm{~N}-\mathrm{NaOH}$ at $0^{\circ}$ for $30 \mathrm{~min}$. Samples of the suspension were neutralized with an equal volume of various acids and centrifuged, and the $\mathrm{pH}$ (glass electrode) and organic phosphate content of the centrifugate were measured. The results given in Table 1 showed that at $\mathrm{pH}$ values below 6 organic phosphate was removed from the solution. It was observed, however, that this removal was not a simple precipitation of nucleic acid, because, when the cells were centrifuged down from the $0 \cdot 1 \mathrm{~N}-\mathrm{NaOH}$ before the $\mathrm{pH}$ was lowered, precipitation of organic phosphate did not occur.

Table 1. Effect of $\mathrm{pH}$ value on re-absorption of $R N A$ fragments extracted in 30 min. from a suspension of Micrococcus pyogenes in $0 \cdot 1 \mathrm{~N}-\mathrm{NaOH}$ at $0^{\circ}$

$\begin{array}{lcc}\text { Solution added to an equal } & \text { Final } \mathrm{pH} & \begin{array}{c}\text { Amount of organic } \\ \text { P left in solution }\end{array} \\ \quad \text { volume of suspension } & 12 \cdot 5 & 86 \\ \text { Water } & 9 \cdot 73 & 86 \\ 0 \cdot 1 \mathrm{M} \text { boric acid } & 9 \cdot 24 & 84 \\ 0 \cdot 1 \mathrm{~m} \text { acetic acid } & 8 \cdot 86 & 84 \\ 0 \cdot 2 \mathrm{M} \text { boric acid } & 5 \cdot 90 & 84 \\ 0 \cdot 033 \text { M citric acid } & 4 \cdot 85 & 59 \\ 0 \cdot 05 \mathrm{M} \text { citric acid } & 4 \cdot 70 & 41 \\ 0 \cdot 2 \mathrm{M} \text { acetic acid } & 3 \cdot 0 & 16 \\ 0 \cdot 1 \mathrm{~N} \text { HCl containing } & & \\ 10 \% \text { (w/v) trichloroacetic acid } & & \end{array}$

Evidently the nucleic acid fragments were adsorbed by components of the cells. This interesting but troublesome effect was eliminated by using an equal volume of $0 \cdot 1 \mathrm{~N}$ acetic acid to neutralize the $0.1 \mathrm{~N}-\mathrm{NaOH}$.

The time course of the extraction of purine-pyrimidine, pentose and organic phosphate of the RNA fraction of $M$. pyogenes could now be determined. A washed cell suspension (dry weight at harvesting $4 \mathrm{mg} . / \mathrm{ml}$.) was extracted with $5 \%$ trichloroacetic acid at $0^{\circ}$ for $30 \mathrm{~min}$. at a dry-weight concentration of $10 \mathrm{mg} . / \mathrm{ml}$., centrifuged, and the cell residue was washed once with distilled water. The cell residue was resuspended at the original dry-weight concentration in $0 \cdot 1 \mathrm{~N}-\mathrm{NaOH}$ at $0^{\circ}$. Samples, taken at intervals, were neutralized with an equal volume of $0.1 \mathrm{~N}$ acetic acid and the cells were centrifuged down from the extracts. Estimations of deoxypentose by the Dische (1930) reaction showed that DNA was not extracted in $0.1 \mathrm{~N}-\mathrm{NaOH}$ at $0^{\circ}$. The components of the RNA fraction occurring in the extracts were therefore examined directly by determinations of organic phosphate, purine-pyrimidine and pentose. The components of the RNA fraction remaining in the cell residue were similarly examined in the solution obtained by treating the residue with $\mathrm{N}-\mathrm{NaOH}$ at $35^{\circ}$ for $15 \mathrm{hr}$., neutralizing with $\mathrm{N}-\mathrm{HCl}$ and reprecipitating the DNA by the 
addition of 0.2 vol. of $30 \%$ trichloroacetic acid. The progress of the extraction is described in Fig. 1 in terms of $\mu$ mol. of pentose, purine-pyrimidine and 'excess phosphate' (XSP) per g. of dry organism found in cell residue and extract. Although the pentose values were consistently low for the cell residues, it is evident that the purine-pyrimidine and pentose were extracted about ten times as quickly as the 'excess phosphate', the half-extraction times being $c .5$ and $50 \mathrm{hr}$. respectively.

Fractional extraction by acid. Preliminary experiments showed that washed suspensions of $\boldsymbol{M}$. pyogenes were considerably more resistant to acid than to alkaline hydrolysis. Extraction of organic phosphate proceeded slowly in

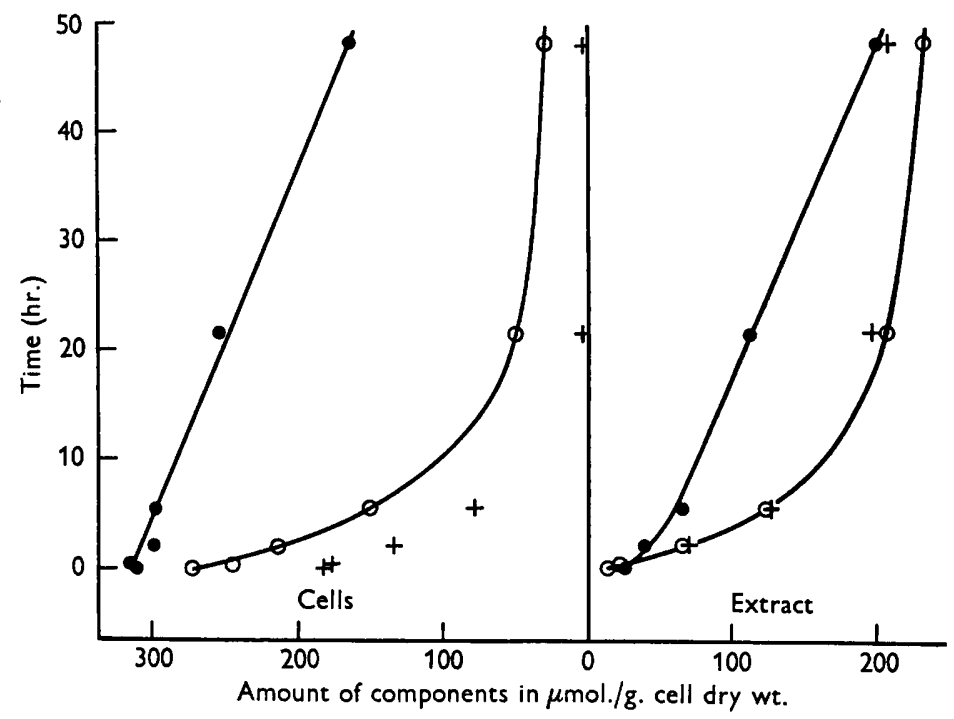

Fig. 1. The time course of the extraction of organic phosphate, purine-pyrimidine and pentose from $M$. pyogenes suspended at a concentration of $10 \mathrm{mg}$. dry wt. $/ \mathrm{ml}$. in $0 \cdot 1 \mathrm{~N}-\mathrm{NaOH}$ at $0^{\circ}$, observed by determinations on both cells and extract. Expressed as $\mu$ mol. of purine-pyrimidine or RNA nucleotide units $(\mathrm{O}-\mathrm{O})$; $\mu$ mol. 'excess phosphate' (XSP $=$ total organic P-RNA) $(\bullet-\bullet)$; and $\mu$ mol. pentose $(+++)$ per g. of dry organism.

$\mathrm{N}-\mathrm{HCl}$ at $0^{\circ}$, and as there was little likelihood of autolytic activity in such an acid solution, the rate of extraction was brought to a convenient level by raising the temperature to $35 .^{\circ}$ The time course of the extraction of purinepyrimidine and organic phosphate was determined as follows. Washed $M$. pyogenes (dry weight at harvesting $1 \mathrm{mg} . / \mathrm{ml}$.) was suspended in $\mathrm{N}-\mathrm{HCl}$ at $35^{\circ}$ at a dry-weight concentration of $10 \mathrm{mg} . / \mathrm{ml}$. Samples were taken at intervals, and the cell residue was centrifuged rapidly from the extract without neutralizing the $\mathrm{HCl}$. The estimations on the cell residues and extracts were carried out as before, pentose estimations being omitted. The initial values for the organic phosphate and purine-pyrimidine content of the extract represented the 'acid soluble' fraction which is usually extracted in $5 \%$ trichloroacetic acid; these values were therefore subtracted from the values subsequently 
obtained, to give the progress curves. Fig. 2 shows that the half-extraction times were about $10 \mathrm{hr}$. for the 'excess phosphate' and $2 \mathrm{hr}$. for the purinepyrimidine. The total organic phosphate and purine-pyrimidine increased with time because the DNA is extracted by the $\mathrm{N}-\mathrm{HCl}$ in $c .3 \mathrm{hr}$. This does not, however, affect the relative rates of extraction of phosphate and purinepyrimidine, for the ratio of phosphate to purine-pyrimidine in the relatively small DNA fraction is near unity. The total 'excess phosphate' of the cells extracted in alkali (Fig. 1) was greater than that of the cells extracted in acid (Fig. 2), because in the latter case the culture of $M$. pyogenes used was harvested at an earlier phase of growth (Mitchell, 1950 b).

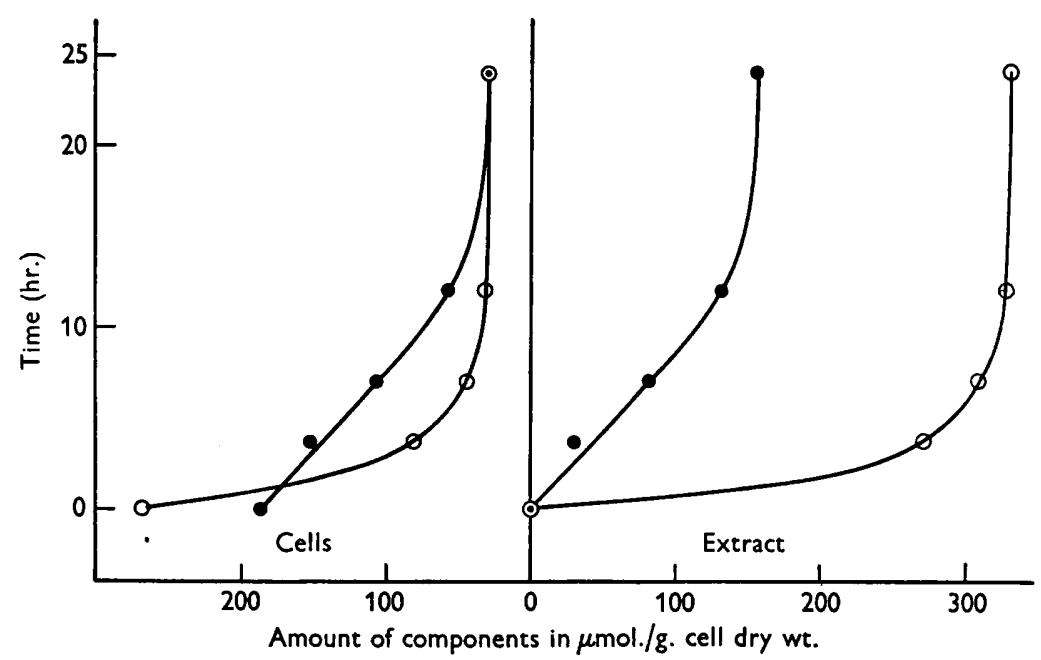

Fig. 2. The time course of the extraction of organic phosphate and purine-pyrimidine from $M$. pyogenes suspended at a concentration of $10 \mathrm{mg}$. dry wt. $/ \mathrm{ml}$. in $\mathrm{N}-\mathrm{HCl}$ at $35^{\circ}$, observed by determinations on both cells and extract. Expressed as $\mu \mathrm{mol}$. of purinepyrimidine $(\mathrm{O}-\mathrm{O})$ and $\mu \mathrm{mol}$. of 'excess phosphate' $\left(\mathrm{O}_{-}\right)$per g. of dry organism.

\section{Isolation and characterization of the carriers of the 'excess phosphate'}

It was likely that the separation of the carriers of the 'excess phosphate' in $\boldsymbol{M}$. pyogenes would be facilitated by a preliminary extraction of most of the nucleic acid with dilute acid or alkali.

Isolation of barium salt. A crude solution of the 'excess phosphate' carriers was obtained by extracting $10 \mathrm{~g}$. dry $M$. pyogenes with $1 \mathrm{l} \cdot 0 \cdot 1 \mathrm{~N}-\mathrm{NaOH}$ at $0^{\circ}$ for $24 \mathrm{hr}$. to remove $\mathrm{RNA}$, solution of the cell residue in $100 \mathrm{ml} . \mathrm{N}-\mathrm{NaOH}$ at $35^{\circ}$, neutralizing with $10 \mathrm{ml}$. $10 \mathrm{~N}-\mathrm{HCl}$ and precipitation of DNA and other contaminants by adding $22 \mathrm{ml}$. of $30 \%$ trichloroacetic acid followed by $530 \mathrm{ml}$. ethanol. The solution yielded a water-soluble ethanol-precipitable barium salt containing $6 \% \mathrm{P}$ and $5 \% \mathrm{~N}$. The nitrogen was present almost exclusively in surface-active, biuret-reacting, non-dialysable substances which could be removed either by foam fractionation or, more easily, by adsorption on activated charcoal. After treatment with 20 g. activated charcoal, the barium salt was repeatedly reprecipitated from water with 2 vol. ethanol. The white 
barium salt thus obtained, free from sulphur, nitrogen and halogen, and containing $9 \% \mathrm{P}$ and $40 \% \mathrm{Ba}$, weighed $230 \mathrm{mg}$., and represented $670 \mu \mathrm{mol}$. of $\mathrm{PO}_{4}$ out of a total $2500 \mu \mathrm{mol}$. of XSP.

General properties of the 'excess phosphate' carriers. The barium salt was soluble in water to the extent of c. $5 \%$. The free acid, prepared by the quantitative precipitation of the barium with sulphuric acid, showed the following preperties. It gave no orcinol reaction for pentose (Mejbaum, 1939) or Dische (1930) reaction for deoxy sugars. A faint Molisch reaction suggested a carbohydrate phosphoric ester, but there was no reducing activity towards either alkaline copper reagents, ferricyanide or dinitrosalicylic acid before or after acid or enzymic hydrolysis. There was no 'rapid furfural', Seliwanoff or Foulger (1932) reaction for sugars or Scherer (1850) reaction for inositol. There was no light absorption between wave-lengths of $2 \mu$. and $240 \mathrm{~m} \mu$. There was a positive acrolein reaction for glycerol.

\begin{tabular}{|c|c|c|c|}
\hline$[\mathbf{M}]$ & $\mathrm{pH}$ & {$\left[\mathrm{Na}^{+}\right]$} & $\mathbf{p} \mathbf{K}^{\prime}$ \\
\hline $3 \cdot 65$ & $2 \cdot 48$ & 0.00 & 1.49 \\
\hline $3 \cdot 62$ & 2.62 & 0.99 & 1.45 \\
\hline $3 \cdot 59$ & $2 \cdot 85$ & 1.98 & 1.62 \\
\hline 3.55 & $3 \cdot 40$ & $2 \cdot 90$ & - \\
\hline $3 \cdot 52$ & 5.05 & 3.85 & - \\
\hline $3 \cdot 48$ & 5.94 & $4 \cdot 75$ & $6 \cdot 17$ \\
\hline $3 \cdot 45$ & 6.51 & 5.65 & $6 \cdot 27$ \\
\hline $3 \cdot 42$ & $7 \cdot 16$ & $6 \cdot 55$ & $6 \cdot 13$ \\
\hline $\mathbf{3} \cdot 38$ & $9 \cdot 13$ & $7 \cdot 40$ & \\
\hline
\end{tabular}

$[M]=$ total concentration of polyolphosphoric acid + sodium salt in $\mathrm{mg}$. atoms $\mathrm{P}$ per litre. $\left[\mathrm{Na}^{+}\right]=$concentration of sodium ion added to the polyolphosphoric acid as $\mathrm{NaOH}$, in mg. ions per litre.

$$
\begin{aligned}
\mathbf{p H} & =-\log _{10}\left[\mathbf{H}^{+}\right] \\
\mathbf{p K ^ { \prime }} & =\mathbf{p H}+\log _{10}\left([\mathrm{M}]+\left[\mathrm{OH}^{\prime}\right]-\left[\mathrm{Na}^{+}\right]-\left[\mathrm{H}^{+}\right]\right)-\log _{10}\left(\left[\mathrm{Na}^{+}\right]+\left[\mathrm{H}^{+}\right]-\left[\mathrm{OH}^{\prime}\right]\right) .
\end{aligned}
$$

The ionization constants were determined by the method of Kumler (1938). A solution of $1.26 \mathrm{mg}$. of the acid in $1 \mathrm{ml}$. distilled water was titrated in a polystyrene electrode vessel with $\mathrm{CO}_{2}$-free $0 \cdot 1 \mathrm{~N}-\mathrm{NaOH}$ using $0.01 \mathrm{ml}$. additions. The $\mathrm{pH}$ values were determined with a bulb type glass electrode giving a linear response over the range from $\mathrm{pH} 1$ to 9 . The results in Table 2 show two $\mathrm{pK}^{\prime}$ values, $c$. $\mathbf{1 . 5}$ and 6.2 , each corresponding to the dissociation of one hydrogen ion per phosphorus atom. In view of the small amount of material titrated, the $\mathrm{pK}^{\prime}$ values might be in error by as much as $\mathbf{\pm 0 . 2} \mathbf{p H}$ unit. According to Kumler \& Eiler (1943), glycerophosphoric acid gives $\mathrm{pK}^{\prime}$ values of $1 \cdot 4$ and $6 \cdot 4$.

Hydrolysis at $100^{\circ}$ for $2 \mathrm{hr}$. in $\mathrm{N}-\mathrm{HCl}$ or $\mathrm{N}-\mathrm{NaOH}$ liberated less than $10 \%$ of the phosphate as inorganic phosphate, thus indicating polyhydric alcohol phosphates (Kaplan \& Greenberg, 1944). Treatment of a solution at pH $9 \cdot 5$ in $0.02 \mathrm{M}$ bicarbonate buffer containing $0.01 \mathrm{M}-\mathrm{MgCl}_{2}$ with a highly purified preparation of the alkaline phosphomonoesterase of milk (kindly supplied by $\mathbf{R}$. K. Morton) at $35^{\circ}$ liberated inorganic phosphate at a rate $c .10 \%$ lower than from a control sample of pure $\beta$-glycerophosphate, the reaction going to completion.

It was concluded that the unknown phosphate-containing material was 
a polyhydric alcohol monophosphoric ester (or a mixture of such esters) contaminated by a small amount of carbohydrate. Henceforward this material is referred to as the polyolphosphate fraction.

Chromatographic analysis of the polyolphosphate fraction. Samples of the polyolphosphate fraction, freed from barium by the theoretical amount of sulphuric acid, were run on paper chromatograms following in detail the methods of Hanes \& Isherwood (1949), with the results shown in Table 3. The main polyolphosphate corresponded to glycerophosphate, but there was a subsidiary component, representing $c .10 \%$ of the total phosphate, running with an $\boldsymbol{R}_{F}$ value of $0.11 \mathrm{in}$ propanol/ammonia.

Table 3. Chromatography of the polyolphosphates

$$
\text { Substance } \boldsymbol{R}_{F} \text { value }
$$

(Solvent: $80 \mathrm{ml}$. tertiary butanol $/ 20 \mathrm{ml}$. water $+2 \mathrm{~g}$. picric acid)

\begin{tabular}{|c|c|}
\hline Polyolphosphate fraction & $0.69-0.65$ \\
\hline$\alpha$-Glycerophosphate & $0 \cdot 655$ \\
\hline$\beta$-Glycerophosphate & $0 \cdot 69$ \\
\hline Glyceric acid 3-phosphate & 0.655 \\
\hline Glyceric acid 2-phosphate & 0.68 \\
\hline
\end{tabular}

(Solvent: $60 \mathrm{ml}$. $n$-propanol $/ 10 \mathrm{ml}$. water $+30 \mathrm{ml} .20 \mathrm{~N}$ ammonia)

$\begin{array}{ll}\text { Polyolphosphate fraction } & 0 \cdot 305 \text { (strong) } 0 \cdot 110 \text { (weak) } \\ \text { a-Glycerophosphate } & 0 \cdot 31 \\ \beta \text {-Glycerophosphate } & 0 \cdot 30 \\ \text { Glyceric acid 3-phosphate } & 0 \cdot 21 \\ \text { Glyceric acid 2-phosphate } & 0 \cdot 29 \\ \text { Fructofuranose 1:6-diphosphate } & 0 \cdot 093 \\ \text { Orthophosphate } & 0 \cdot 14\end{array}$

Chromatograms were run at $25^{\circ}$ on Whatman no. 1 paper washed with dilute acetic acid. For comparison of the above $R_{F}$ values with those for other phosphate esters see Hanes \& Isherwood (1949).

Chromatographic analysis of the polyols. Dephosphorylation of $25 \mathrm{mg}$. of the polyolphosphoric acid was carried out with the milk phosphatase under the same conditions as before. The inorganic phosphate was precipitated with excess barium hydroxide, and barium and magnesium removed by passing the solution through a small acid-washed Zeocarb column. The solution was then dried in vacuo over $\mathrm{P}_{2} \mathrm{O}_{5}$ and sodium hydroxide pellets, the latter being required to take up $\mathrm{HCl}$ and $\mathrm{CO}_{2}$. A yield of $12 \mathrm{mg}$. of a viscous liquid, miscible with water and with ethanol, was obtained. This material was run on paper chromatograms in $n$-butanol/water, using development with ammoniacal silver nitrate according to the method of Hough (1950). Table 4 shows that the main component behaved like glycerol, but there was a subsidiary component, approximately corresponding in amount to the subsidiary polyolphosphate, running with an $R_{F}$ value of $\mathbf{0 . 1 3}$, the same as xylose. When developed with ammoniacal silver nitrate, the reducing sugars were found to give rise to rapidly appearing brown spots, whereas the polyhydric alcohols developed more slowly, giving black spots. The subsidiary polyol behaved like a polyhydric alcohol during development.

$A$ water-insoluble barium polyolphosphate fraction. During the purification of the polyolphosphate fraction by repeated precipitation of the barium salt 
from aqueous solution with 2 vol. ethanol, a water-insoluble barium salt fraction was eliminated. This fraction consisted mainly of barium phosphate but some organic phosphate was also present. When examined on propanol/ ammonia chromatograms, the organic component of the water-insoluble barium salt fraction was found to correspond to the subsidiary polyolphosphate of the water-soluble barium polyolphosphate fraction $\left(R_{F}=0 \cdot 11\right)$. After hydrolysis with the milk phosphatase it gave rise to a polyol chromatographically identical with the subsidiary polyol derived from the watersoluble polyolphosphate fraction $\left(R_{F}=0.13\right.$ in $n$-butanol/water) and a smaller quantity of a substance running like glycerol. Like the water-soluble barium salt fraction, the water-insoluble barium polyolphosphate fraction showed no reducing activity even towards dinitrosalicylic acid before or after acid or enzymic hydrolysis.

\section{Table 4. Chromatography of the polyols}

\begin{tabular}{ll}
\multicolumn{2}{c}{ Solvent: $n$-butanol/water } \\
Substance & $R_{F}$ value \\
Polyol fraction & $0 \cdot 350$ (strong) $\mathrm{Bl}$. 0.130 (weak) Bl. \\
Propylene glycol & $0 \cdot 64 \mathrm{Bl}$. \\
Ethylene glycol & $0 \cdot 57 \mathrm{Bl}$. \\
Glycerol & $0 \cdot 35 \mathrm{Bl}$. \\
Diglycerol & $0 \cdot 25 \mathrm{Bl}$. \\
meso-Erythritol & $0 \cdot 22 \mathrm{Bl}$. \\
D-Ribose & $0 \cdot 17 \mathrm{Br}$. \\
D-Xylose & $0 \cdot 13 \mathrm{Br}$. \\
Mannitol & $0 \cdot 085 \mathrm{Bl}$. \\
D-Glucose & $0 \cdot 073 \mathrm{Br}$. \\
D-Mannose & $0 \cdot 021 \mathrm{Br}$. \\
meso-Inositol & $0 \cdot 007 \mathrm{Bl}$.
\end{tabular}

Chromatograms run at $25^{\circ}$ on Whatman no. 1 paper washed with dilute acetic acid. $\mathrm{Bl}$.= black spot developing slowly. $\mathrm{Br} .=$ brown spot developing rapidly.

Identification of the water-soluble barium polyolphosphate. The water-soluble barium salt fraction was freed from 'water-insoluble' barium polyolphosphate and contaminating carbohydrate by treatment of a $5 \%$ aqueous solution with activated charcoal followed by talc, precipitating the barium salt with 2 vol. ethanol, twice reforming the $5 \%$ aqueous solution (discarding insoluble material) and precipitating the barium salt with 2 vol. ethanol. After drying to constant weight in vacuo at $100^{\circ}$ over $\mathrm{P}_{2} \mathrm{O}_{5}$, two different preparations, obtained in a yield of $120 \mathrm{mg}$. of barium salt from the equivalent to $10 \mathrm{~g}$. of M. pyogenes gave on analysis: $9.5 \% \mathrm{P} ; \mathbf{4 3 . 2} \% \mathrm{Ba}$, and $10 \cdot 1 \% \mathrm{P} ; \mathbf{4 4 . 0} \% \mathrm{Ba}$, corresponding satisfactorily to barium glycerophosphate, $\mathrm{C}_{3} \mathrm{H}_{7} \mathrm{O}_{6} \mathrm{PBa}+\frac{1}{2} \mathrm{H}_{2} \mathrm{O}$ : $9.79 \% \mathrm{P} ; 43.42 \% \mathrm{Ba}$. The identity of the water-soluble barium polyolphosphate as barium glycerophosphate was considered to be proved.

Further chromatographic analysis of the water-insoluble barium polyolphosphates. Samples of the water-insoluble barium polyolphosphate fraction which were judged to be free from glycerophosphate on the basis of chromatograms in propanol/ammonia were found to give as much as $20 \%$ of glycerol 
after dephosphorylation with the milk phosphatase. This fraction was therefore suspected of being complex. A separation into two components with $\boldsymbol{R}_{F}$ values of 0.62 and 0.73 was obtained in the tert.-butanol/picric acid solvent of Hanes \& Isherwood (1949). Using a more acidic solvent consisting of equal volumes of $n$-butanol and $\mathrm{N}-\mathrm{HCl}$, a better separation into components with $\boldsymbol{R}_{F}$ values of 0.22 and 0.41 was achieved. The $R_{F}$ value of $\beta$-glycerophosphate in $n$-butanol $/ \mathrm{N}-\mathrm{HCl}$ was $0 \cdot 39$, and it therefore seemed possible that the spot with $\boldsymbol{R}_{F}=\mathbf{0 . 4 1}$ might represent glycerophosphate formed from the unknown polyol phosphate by the N-HCl. Two-dimensional chromatograms, run first in $n$-butanol/N-HCl and then in propanol/ammonia, showed that both the components appearing on the butanol/HCl chromatograms gave an $\boldsymbol{R}_{F}$ value of 0.11 when subsequently run in propanol/ammonia. Neither component could therefore have corresponded to glycerophosphate, which has an $R_{F}$ value of $0 \cdot 30-0 \cdot 31$ in propanol/ammonia. Further characterization of the waterinsoluble polyolphosphate fraction was postponed while larger amounts of material were collected. The work now in progress on this material will be published in due course.

Conclusions. It was evident that $M$. pyogenes must contain a phosphocompound, not extracted by organic solvents, from which glycerophosphate is released on hydrolysis with alkali. The components of the water-insoluble barium polyolphosphate fraction must also have been similarly released either from the same or from some other phospho-compound. In view of the low yields and of the obvious selectivity of our fractionation procedures, it was not known whether the major proportion of the 'excess phosphate' might be accounted for in this way. Moreover, it was uncertain to what extent the treatment with alkali might determine the nature of the phosphate-containing fragments. It was therefore desirable to carry out the fractionation in a more quantitative manner, using as starting material both the crude extract obtained by alkali treatment of $M$. pyogenes and that obtained by an analogous acid extraction.

\section{Quantitative fractionation of alkali- and acid-extracted 'excess phosphate'}

Growth and organic phosphate distribution of M. pyogenes. A 41. culture of $\boldsymbol{M}$. pyogenes was grown at $25^{\circ}$ to a dry-weight concentration of $3 \mu \mathrm{g} . / \mathrm{ml}$. in a 10 l. rotated flask (Mitchell, 1949) in our casein digest medium containing $1 \%(\mathrm{w} / \mathrm{v})$ glucose and $0 \cdot 1 \%$ Marmite. After centrifuging, the cells were washed twice in distilled water, cooled with solid $\mathrm{CO}_{2}$ in acetone and dried in the frozen state over $\mathrm{P}_{2} \mathrm{O}_{5}$ in a vacuum desiccator. Estimation of the distribution of the organic phosphate gave the results shown in Table 5, expressed as $\mu$ mol. phosphate per g. dry-weight organism. For comparison with Table 5, the yields obtained in the extraction and fractionation procedures described below are expressed as $\mu \mathrm{mol}$. RNA nucleotide units (estimated as purinepyrimidine) and $\mu$ mol. XSP (=total organic P-RNA) per g. dry-weight organism. In preparation for the alkali and acid extraction, lipid was exhaustively extracted from two $5 \mathrm{~g}$. samples of dried organism by repeatedly heating under reflux with $95 \%$ aqueous methanol for $1 \mathrm{hr}$, evaporating to 
dryness and extracting in a Soxhlet apparatus with sodium-dried ether (Reichert, 1944).

Alkali extraction. A 5 g. sample of dried organism, freed from lipid, was dispersed in $100 \mathrm{ml}$. $0.1 \mathrm{~N}-\mathrm{NaOH}$ and held at $0^{\circ}$ for $19 \mathrm{hr}$, neutralized with $100 \mathrm{ml} .0 \cdot 1 \mathrm{~N}$ acetic acid, centrifuged, and the centrifugate discarded. The cell residue was washed once with $0.1 \mathrm{~N}$ sodium acetate and dissolved in $50 \mathrm{ml}$. $\mathrm{N}-\mathrm{NaOH}$ by incubation at $35^{\circ}$ for $15 \mathrm{hr}$. To this solution, $5 \mathrm{ml} .10 \mathrm{~N}-\mathrm{HCl}$ and $9 \mathrm{ml} .30 \%(\mathrm{w} / \mathrm{v})$ trichloroacetic acid were added, and after $30 \mathrm{~min}$. at room temperature, the precipitate was centrifuged down and discarded. The centrifuged liquid was adjusted to $\mathrm{pH} 8$ with $4 \mathrm{~N}-\mathrm{NaOH}$ and made up to $150 \mathrm{ml}$. with distilled water. Yield: $\mathrm{RNA}=191, \mathrm{XSP}=\mathbf{2 4 6}$, the units being $\mu \mathrm{mol} . / \mathrm{g}$. as defined above.

Table 5. Distribution of organic phosphate in Micrococcus pyogenes

\section{Component}

Free nucleotides and other components extracted in cold $5 \%$ trichloroacetic acid

Phospholipid

'Phosphoprotein'

DNA

RNA (as defined in text)

XSP (as defined in text)

Total

\begin{tabular}{|c|c|}
\hline \multicolumn{2}{|c|}{ Phosphorus distribution } \\
\hline $\begin{array}{l}\mu \mathrm{mol} . \mathrm{P} / \mathrm{g} . \\
\text { cell dry wt. }\end{array}$ & $\%$ of total $\mathrm{F}$ \\
\hline 119 & 17 \\
\hline 38 & 6 \\
\hline$<1$ & \\
\hline 77 & 11 \\
\hline 197 & 29 \\
\hline 250 & 37 \\
\hline 681 & 100 \\
\hline
\end{tabular}

Acid extraction. 5 g. sample of dried organism, freed from lipid, was dispersed in $250 \mathrm{ml} . \mathrm{N}-\mathrm{HCl}$ and held at $35^{\circ}$ for $4 \mathrm{hr}$., centrifuged, and the centrifugate discarded. The cell residue was washed once with $\mathrm{N}-\mathrm{HCl}$ and resuspended in $90 \mathrm{ml} . \mathrm{N}-\mathrm{HCl}$ at $35^{\circ}$ for $20 \mathrm{hr}$. The residue was centrifuged down and discarded, and to the centrifuged liquid $22 \mathrm{ml} .4 \mathrm{~N}-\mathrm{NaOH}$ and $20 \mathrm{ml} .30 \%(\mathrm{w} / \mathrm{v})$ trichloroacetic acid were added. The precipitate was removed by centrifuging and the supernatant liquid adjusted to $\mathrm{pH} 8$ with $4 \mathrm{~N}-\mathrm{NaOH}$ and made up to $150 \mathrm{ml}$. with distilled water. Yield: $\mathbf{R N A}=\mathbf{2 5}, \mathrm{XSP}=198$.

Fractionation. The same fractionation procedure was used for both alkali and acid extracts. To the extract in a $500 \mathrm{ml}$. flask, $300 \mathrm{ml}$. ethanol was added. After 2 days, the fine precipitate formed by the ethanol had become attached to the glass and the clear supernatant was quantitatively decanted. To this supernatant, $10 \mathrm{ml}$. $\mathrm{M}$ barium acetate was added; the precipitate of barium salt allowed to aggregate overnight, and was then collected on the centrifuge, washed with $60 \%(\mathrm{v} / \mathrm{v})$ aqueous ethanol and dried in vacuo over $\mathrm{P}_{2} \mathrm{O}_{5}$. The barium salt was extracted by grinding 10 times with $5 \mathrm{ml}$. volumes of distilled water, adjusting to $\mathrm{pH} 6$ with $\mathrm{HCl}$ during extraction. Yields thus obtained from the barium salt were: from alkali extract, $\mathrm{RNA}=147, \mathrm{XSP}=214$; from acid extract, $R N A=25, X S P=151$. The barium salt solution was adjusted to pH 8 in preparation for passage through an acid-washed charcoal column prepared as follows. A suspension of 10 g. of 'B.D.H. animal charcoal' (British Drug Houses Ltd.) in water was packed onto two thicknesses of Whatman 
no. 1 filter-paper previously covered with a thin layer of talc in a $10 \mathrm{~cm}$. Buchner funnel, and successively washed under gentle suction with $250 \mathrm{ml}$. $0.1 \mathrm{~N}-\mathrm{HCl}, 100 \mathrm{ml} .5 \% \mathrm{KCl}, 10 \mathrm{ml} .0 \cdot 1 \mathrm{M}-\mathrm{Ba}(\mathrm{OH})_{2}$ and $100 \mathrm{ml} .5 \% \mathrm{KCl}$. The solution of the barium salt was drawn slowly through the charcoal column, followed by five lots of $50 \mathrm{ml}$. of $5 \% \mathrm{KCl}$. The solution was readjusted to pH 8 with barium hydroxide, and the barium salt precipitated by the addition of 4 vol. ethanol and dried in vacuo over $\mathrm{P}_{2} \mathrm{O}_{5}$. Yields: from alkali extract, $145 \mathrm{mg}$. of barium salt per $\mathrm{g}$. of organism, containing $\mathrm{RNA}<1, \mathrm{XSP}=214$; from acid extract, $94 \mathrm{mg}$. of barium salt per $\mathrm{g}$. of organism, containing RNA $<1$, XSP $=116$.

The barium salt was extracted with $5 \mathrm{ml}$. of $0 \cdot 1 \mathrm{~N}-\mathrm{HCl} / 100 \mathrm{mg}$. and the residue was centrifuged down and discarded. The solution was partially separated into water-insoluble and water-soluble barium salt fractions by three successive precipitations of the acidified barium salt with barium hydroxide and precipitation of the soluble barium salt from the supernatant with 4 vol. ethanol. Yields: (as $\mu$ mol. organic phosphate per g. dry organism) from alkali extract, soluble fraction $=187$, insoluble fraction $=17$; from acid extract, soluble fraction $=88$, insoluble fraction $=31$.

In order to obviate the losses inherent in obtaining a complete separation of the soluble and insoluble barium salts, the relative amounts were estimated by determining chromatographically the degree of mutual contamination of the partially separated fractions. The fractions were run on duplicate paper chromatograms in propanol/ammonia, using $0.01 \mathrm{ml}$. samples of $1 \%$ solutions of the barium salt fractions converted to the free acids by treatment with the theoretical amounts of sulphuric acid. One chromatogram was developed to show the positions of the spots so that the appropriate areas $(1 \times 1.5 \mathrm{~cm}$.) could be cut out of the duplicate chromatogram, eluted in $5 \mathrm{ml}$. water, and the organic phosphate determined in the usual way. The weight of phosphorus required in each spot fell in a convenient range between 0.5 and $10 \mu \mathrm{g}$. The chromatograms showed that only glycerophosphate and the unidentified polyolphosphates with $R_{F}=\mathbf{0} \cdot 11$ were present. The ratio of the weight of phosphate in the glycerophosphate (GP) spot to that in the spot given by the water-insoluble barium polyolphosphates (IP) was as follows: from alkali extract, water-soluble fraction GP/IP $>100$, water-insoluble fraction GP/IP = 0.09; from acid extract, water-soluble fraction $\mathrm{GP} / \mathrm{IP}=\mathbf{9 \cdot 3}$, water-insoluble fraction GP/IP $<0.01$. Of the $250 \mu \mathrm{mol}$. total XSP, the yields of GP and IP were thus: from alkali extract $\mathrm{GP}=188, \mathrm{IP}=16$, giving a total recovery of $81 \%$; and from acid extract $G P=80, I P=39$, giving a total recovery of $48 \%$.

Chromatograms of the water-insoluble barium polyolphosphate fraction in $n$-butanol/N-HCl showed that the two components $\left(\boldsymbol{R}_{F}\right.$ values 0.22 and $\left.\mathbf{0 . 4 1}\right)$ were present in this fraction both after alkali and after acid extraction.

Determination of $\alpha$-and $\beta$-glycerophosphate. The glycerophosphate fraction from the acid extract was submitted to further fractionation to remove the remaining water-insoluble barium polyolphosphate. This material and the glycerophosphate fraction from the alkali extract (already free from other polyolphosphates) were assayed for $\alpha$ - and $\beta$-glycerophosphate following in 
detail the periodate oxidation method of Burmaster (1946). The glycerophosphate from the alkali extract assayed as $60 \% \beta$ - and $40 \% \alpha$-, while that from the acid extract assayed as $43 \% \beta$ - and $57 \% \alpha$-glycerophosphate.

Collection of data. The quantities and yields of the polyolphosphates representing the 'excess phosphate' are set out in Table 6.

Table 6. The yields of the carriers of the 'excess phosphate' (XSP)

\begin{tabular}{|c|c|c|}
\hline Component & $\begin{array}{l}\mu \mathrm{mol} . \mathrm{P} / \mathrm{g} . \\
\text { cell dry wt. }\end{array}$ & $\begin{array}{c}\text { Recovery } \\
\text { of total XSP } \\
(\%)\end{array}$ \\
\hline \multicolumn{3}{|l|}{ From alkali extract } \\
\hline$\alpha-\mathbf{G P}$ & 113 & 45 \\
\hline$\beta$-GP & 75 & $\mathbf{3 0}$ \\
\hline Total GP & 188 & 75 \\
\hline IP & 16 & 6 \\
\hline Total polyolphosphate & 204 & 81 \\
\hline \multicolumn{3}{|l|}{ From acid extract } \\
\hline$\alpha-G P$ & 46 & 18 \\
\hline$\beta$-GP & 34 & 14 \\
\hline Total GP & 80 & 32 \\
\hline IP & 39 & 16 \\
\hline Total polyolphosphate & 119 & 48 \\
\hline
\end{tabular}

\section{DISCUSSION}

Our experimental observations lead to the conclusion that there is present in $\boldsymbol{M}$. pyogenes an easily hydrolysed glycerophospho-compound of which the phosphate accounts for at least $75 \%$ of the 'excess phosphate' of the RNA fraction and for at least $27 \%$ of the total organic phosphate of the organism harvested towards the end of growth. It is difficult to believe that so large a phosphate fraction should have remained unobserved, but we have been unable to find any previous reference to its existence.

It was not possible to determine the proportions of $\alpha$-and $\beta$-glycerophosphate in the glycerophospho-compound because of the migration of the phosphate between the $\alpha$ and $\beta$ positions during extraction. The proportions of $\alpha$-and $\beta$-glycerophosphate found after alkali extraction $(60 \% \beta$ and $40 \% \alpha)$ may be compared with the observation of Bailly \& Gaume (1934) that the methyl ester of either $\alpha$ - or $\beta$-glycerophosphate gives rise to $2 / 3 \beta$ - and $1 / 3 \alpha$-glycerophosphate on alkaline hydrolysis. In acid, on the other hand, Bailly (1938) found that $\beta$-glycerophosphate is converted almost quantitatively to the $\alpha$-glycerophosphate form. The glycerophosphate isolated from the acid extract (43 $\% \beta$ and $57 \% \alpha$ ) might have contained $\beta$-glycerophosphate produced during hydrolysis of esters of $\alpha$-glycerophosphate, or $\alpha$-glycerophosphate produced from free $\beta$-glycerophosphate or both.

The yield of glycerophosphate from the acid extraction was about half that obtained from the alkali extraction. Most of the loss of glycerophosphate from the acid extraction is accounted for by the loss of XSP which occurs during the preliminary acid extraction of RNA. In the alkali extraction, on the other hand, the preliminary extraction of alkali-soluble components 
resulted in practically no loss of XSP and very little extraction of RNA, the latter being removed on the activated charcoal column at a later stage. This unintentional improvement in the extraction procedure was caused by raising the concentration of the cell suspension in the $0 \cdot 1 \mathrm{~N}-\mathrm{NaOH}$ from 10 to $50 \mathrm{mg} . / \mathrm{ml}$.

The yield of the two unidentified polyolphosphates was about three times as great from the acid extraction as from the alkali extraction. This difference is susceptible of two possible explanations. It is possible that, as with the relative formation of $\alpha$ - and $\beta$-glycerophosphate, the hydrolytic conditions of the extraction procedure determine the amount of the unidentified polyolphosphates formed relative to that of glycerophosphate from a common precursor. On the other hand, the difference between the yields might be due entirely to the selectivity of the extraction procedures. If the latter be the case, the total amount of the 'excess phosphate' which has been accounted for is the sum of the GP obtained from the alkali extraction and the IP obtained from the acid extraction, namely, $227 \mu \mathrm{mol} . / \mathrm{g}$. or $91 \%$ of the total XSP.

The presence of 'excess phosphate' in a number of Gram-positive organisms (Mitchell, 1950b; Mitchell \& Moyle, 1950) suggests that a glycerophosphocompound similar to that of $M$. pyogenes may be of general occurrence in Gram-positive bacteria and in yeasts, a possibility now under examination in our laboratory.

We would like to acknowledge the receipt of grants in aid of this work from the Medical Research Council.

\section{REFERENCES}

BaIlLy, M. C. (1938). Sur un mode simple et presque quantitatif de passage des $\beta$ - aux $a$-glycérophosphates. C.R. Acad. Sci., Paris, 206, 1902.

BaIlly, O. \& Gaumé, J. (1934). Migration du radical phosphorique au cours de l'hydrolyse du diester methyl- $\beta$-glycérophosphorique. Passage des $\beta$ - aux a-glycérophosphates. C.R. Acad. Sci., Paris, 199, 793.

Burmaster, C. F. (1946). Microdetermination of $\alpha$ - and $\beta$-glycerophosphates. J. biol. Chem. 164, 233.

Dische, Z. (1930). Über einige neue characteristische Farbreaktionen der Thymonucleïnsäure und eine Mikromethode zur Bestimmung derselben in tierischen Organen mit Hilfe dieser Reaktionen. Mikrochemie, 8, 4 .

Fiske, C. H. \& Subbarow, Y. (1925). The colorimetric determination of phosphorus. J. biol. Chem. 66, 375.

Foulger, J. H. (1932). Two new color tests for hexoses. J. biol. Chem. 99, 207.

Hanes, C. S. \& Isherwood, F. A. (1949). Separation of the phosphoric esters on the filter paper chromatogram. Nature, Lond., 164, 1107.

Hougr, L. (1950). Application of paper partition chromatography to the separation of polyhydric alcohols. Nature, Lond., 165, 400.

Kaplan, N. O. \& Greenberg, D. M. (1944). Studies with radioactive phosphorus of the changes in the acid-soluble phosphates in the liver coincident to alterations in carbohydrate metabolism. 1. Separation and nature of the organic acidsoluble phosphates of liver. J. biol. Chem. 156, 511.

KumLER, W. D. (1938). The dissociation constants of some enols related to $l$-ascorbic acid. Tetronic acid, $a$-chlorotetronic acid, $a$-bromotetronic acid, $a$-iodotetronic acid, $a$-hydroxytetronic acid and ethyl $a$-iodoacetate. J. Amer. chem. Soc. 60, 859. 
Kumler, W. D. \& Eiler, J. J. (1943). The acid strength of mono- and diesters of phosphoric acid. The $n$-alkyl esters from methyl to butyl, the esters of biological importance and the natural guanidine phosphoric acids. J. Amer. chem. Soc. 65, 2355.

Malmaren, B. \& Hedén, C. G. (1947). Studies of the nucleotide metabolism of bacteria. 1. Ultraviolet microspectrography as an aid in the study of the nucleotide content of bacteria. Acta path. microbiol. scand. 24, 417.

Mejbaum, W. (1939). Über die Bestimmung kleiner Pentosemengen insbesondere in Derivaten der Adenylsäure. Hoppe-Seyl. Z. 285, 117.

Mrtchell, P. (1949). A new technique for stirred aerated culture. Nature, Lond., $164,846$.

MrTcheLL, P. $(1950 a)$. Spectrophotometric estimation of nucleic acid in bacterial suspensions. J. gen. Microbiol. 4, 399.

Mrtchell, P. $(1950 \mathrm{~b})$. Nucleic acid synthesis and the bactericidal action of penicillin. Ph.D. Thesis, Cambridge.

Mitchell, P. \& MoYLe, J. (1950). Occurrence of a phosphoric ester in certain bacteria: its relation to Gram staining and penicillin sensitivity. Nature, Lond., 166, 218.

Mrtchell, P. \& Moyle, J. (1951). Relationships between cell growth, surface properties and production of free nucleotide and nucleic acids in normal and penicillin-treated Micrococcus pyogenes. J. gen. Microbiol. 5, 421.

Reichert, R. (1944). Quantitative Bestimmung des Gesamtlipoidgehaltes von Naturstoffen. Helv. chim. Acta, 27, 961.

Scherer, J. (1850). Neue, aus dem Muskelfleische gewonnene Zuckerart. Liebigs Ann. 73, 322.

Schmidt, G. \& Thannhauser, S. J. (1945). A method for the determination of desoxyribonucleic acid, ribonucleic acid and phosphoproteins in animal tissues. J. biol. Chem. 161, 83.

Schneider, W. C. (1945). Phosphorus compounds in animal tissues. 1. Extraction and estimation of desoxypentose nucleic acid and of pentose nucleic acid. J. biol. Chem. 161, 293.

Sevag, M. G. \& Smolens, J. (1941). Studies on the conjugation of streptococcal nucleoprotein. J. biol. Chem. 140, 833.

Stephenson, M. \& MoYLe, J. (1949). Nucleic acid metabolism of Escherichia coli. Biochem. J. 45, vii.

VALYI-NAGY, T. (1947). Beiträge zur kolorimetrischen Bestimmung der Pentosen, Nucleoside and Nucleotide. Z. Vitamin-, Hormon Fermentforchung, 1, 279.

Wyatt, G. R. (1950). Insect viruses and nucleic acids. Ph.D. Thesis, Cambridge. 